\title{
A RESPONSE ARTICLE TO 'HELPFUL MODELS OF THEOLOGICAL, MORAL, AND SPIRITUAL DISCERNMENT IN CATHOLICISM, PROTESTANTISM, AND ORTHODOXY BY KATEŘINA BAUER, FRANTIŠEK ŠTĚCH, AND MICHAELA KUŠNIERIKOVÁ'
}

V I O R E L C O M A N

ABSTRACT

This article constitutes a brief response to the reflections of Katerina Bauer, František Štěch, and Michaela Kušnieriková on helpful models of theological, moral, and spiritual discernment, emphasising that the meta-praxis of discernment is needed in order to theoretically reflect on diakrisis and its theological, spiritual, and moral aspects. The article continues with a couple of remarks on discernment in Catholicism, Protestantism, and Orthodoxy. The article focuses on (i) discernment as the art of learning and listening; (ii) the practice of discernment as an ongoing hermeneutical re-reading of the past experiences and traditions; and (iii) false forms of discernment.

Key words

Discernment; Dialogue; Orthodox Theology; Ecumenism; Spirituality; Hermeneutics

DOI: $10.14712 / 23363398.2020 .6$

$\mathrm{T}$

he excellent article that I have been invited to respond to explores the topic of discernment and its associated themes in the form of a conversation between three theologians coming from different Christian traditions: Kateřina K. Bauer (Orthodox), František Štěch (Roman Catholic), and Michaela Kušnieriková (Protestant). Before I start my brief response, I would like to point out that I find the topic of their article acutely relevant for the contemporary Church, academia, and society; we no longer inhabit today - especially in Europe, but in 
some other parts too - a society which is homogenous and uniform, but a space colored by religious, social, and cultural plurality, where the variety of opinions, choices, and experiences renders the praxis of diakrisis (the Greek term for 'discernment') an invaluable tool that helps us decipher our own way and our own path towards salvation. It comes without any surprise that patristic tradition refers to discernment as to 'the queen of all the virtues'. ${ }^{1}$ Moreover, the praxis of discernment, as 'the process of inquiry of what is true and false, good and wrong', ${ }^{2}$ just to use the definition provided by František Štěch in the article, is all the more important as our contemporary society is increasingly dominated by a series of phenomena such as fake news, alternative facts, and disinformation.

When it comes to the article I was invited to respond to, I would like to begin with a couple of general remarks. The fact that it is written and presented in a form of a dialogue between three theologians pertaining to different Christian churches confirms that, in the academia - yet not only in the academia, discernment should always function as a sort of a meta-praxis, that is, as the guiding methodology of every discourse and reflection: the article of Kateřina Bauer, František Štěch, and Michaela Kušnieriková indicates that, in order to speak on discernment, one needs a kind of meta-discernment, that is the human capacity or ability to offer the correct interpretation of what diakrisis means in reality. ${ }^{3}$ In other words, one needs a strong dose of meta-discernment

1 Stanley S. Harakas, Towards Transfigured Life: The Theoria of Eastern Orthodox Ethics (Minneapolis: Light and Life, 1983), 212.

2 Christianity speaks of discernment as the effort to understand God's will and to align the believer's will with that of God's. For example, Donald K. McKim defines theological discernment as 'the process of assessing and evaluating, particularly in relation to trying to determine God's will in a particular situation for one's life direction' - Westminster Dictionary of Theological Terms (Louisville: Westminster John Knox Press, 1996), 78. In a similar way, the Russian Orthodox theologian from the Parisian diaspora Paul Evdokimov refers to the notion of discernment as the spiritual charism of the human person that makes him/her capable (i) of distinguishing between right and wrong and (ii) of making decisive choices. See Paul Evdokimov, Ages of the Spiritual Life (Crestwood: St. Vladimir's Seminary Press, 2000), 190. Although the notion of discernment is an important concept in the Church, not all dictionaries dedicated to Christianity refer to it. See, for example L. Cross and E. A. Livingstone (eds.), The Oxford Dictionary of the Christian Church (Oxford: University Press, 1998).

3 A similar idea is expressed by the American theologian Paul Gavrilyuk in his unpublished paper entitled 'John Climacus and Spiritual Discernment'. As P. Gavrilyuk says in this paper, 'the practice of discernment is [...] somewhat circular: we need a measure of discernment to analyze and reflect on discernment' (p. 1). Gavrilyuk's paper 
to reflect theoretically on the nature, practice, and significance of discernment. The meta-praxis of discernment that has felicitously been chosen by the authors of the article to navigate through the complexity of the practice of diakrisis and its theological, moral, and spiritual dimensions is the method of dialogue, conversation, and exchange of opinions. The method of dialogue is the place where the personal dimension of discernment encounters both the otherness and the collective wisdom of the group, which allows individual voices to be heard and creates space for a 'non-fundamentalist approach to truth about God, oneself, and the world', as it is mentioned in the introduction of the article. Discernment in the form of dialogue shows that human persons do not own or poses truth, but truth is given to them when they create space for alterity to flourish and when they are willing to listen to and to receive from their partners of conversation. In this sense, what I found interesting in their article is its emphasis on the praxis of discernment as a co-journey: one finds the truth in a dialogical and relational process. The very best of our lives is always achieved through dialogue with the other. Dialogue creates a space where each person can share ideas, insights, and questions.

The meta-practice of diakrisis is also traceable in this article when the authors speak of discernment without neglecting the fact that, even though one can theoretically postulate a distinction between theological, moral, and spiritual discernment, these three levels must not be separated from one another: without spiritual discernment, theologically motivated moral decisions are disembodied, while spiritual discernment without theology and morality is rootless. In so doing, the three authors defined discernment as an art, which requires two main things. On the one hand, it is the fidelity to the theological and moral rules that come to us from the past, that is, I would say, the objective element of tradition: the human person acquires discernment if he/she embodies a set of pre-established ethical rules or if he/she follows the path that has been followed by others in the past. On the other hand, the art of discernment requires faithfulness to the spiritual, embodied, and contextually-determined aspect of human existence. In this regard, discernment is also an ongoing and dynamic conversation with God, where the application of ethical rules implies attentiveness to the

was delivered at the 26th International Ecumenical Conference on Orthodox Spirituality, Monastery of Bose, 5-8 September 2018. 
uniqueness of the human person, to the fact that each human being has to respond to each new situation in a personal and unique way. This is, I would say, the more subjective nature of discernment; the freedom of the human person in the process of discernment is at stake here. Accumulated wisdom and norms help, but discernment is always a personal response in a specific and concrete situation. ${ }^{4}$ In this sense, I read the reflections of Kateřina Bauer, František Štěch, and Michaela Kušnieriková on the three aspects of discernment and the need to keep them together as a balanced approach to the twin-fidelities that I have just indicated in regard to the art of diakrisis: faithfulness to tradition and fidelity to innovation and newness.

After these general observations regarding discernment, my response article now turns to offer some reflections on a couple of important theological points connected to the practice of diakrisis that have emerged in the conversation between Kateřina Bauer, František Štěch, and Michaela Kušnieriková. It is from the perspective of an Orthodox theologian and with the problems confronting the Orthodox Christian world in mind that I approach the conversation between the three authors on discernment.

\section{Discernment as the Art of Listening and Learning}

As an Orthodox theologian whose Church is, generally speaking, somehow self-centered and less willing to adopt a learning position in its relation to other churches, religions, and the world, I consider Michaela Kušnierikovás response to the question whether discernment is a dialogue as being of a crucial relevance. As Dr. Kušnieriková rightly

4 Richard M. Gula alludes to this when he says that 'the meaning and function of discernment [...] may be seen by comparing our relationship to God to an ongoing conversation with a friend. God speaks and we respond. In a conversation, no set rules of grammar tell us what to say next. The conversation progresses on the basis of fine feelings picking up the mood and attitude of the other as well as the meaning of the issue under discussion. The grammar which makes language intelligible to the conversation partner is like the moral norms which make action intelligible within a community of shared values. If we speak according to proper grammar, we can understand each other. But grammar does not tell us what to say next in a conversation. Discernment does. In the moral life, a gap exists between moral norms and one's personal imperative in a situation. Norm can direct us toward what we ought to do, but discernment ultimately leads us to the action most expressive of ourselves and of our relationship with God.' Richard M. Gula, Reason Informed by Faith: Foundations of Catholic Morality (New York: Paulist Press, 1989), 314. 
pointed out, 'each of the three discernments (theological, moral, and spiritual) consists of dialogue, of which listening is a crucial part. Listening to those with whom we share not only hymns and pews, but the world, lives, our concerns, and ideas with all regardless if they are Christian, religious, agnostics or atheists, is a crucial aspect of any spiritual discernment.'

My general observations with regard to the practice of discernment alluded already to the dialogical component of diakrisis; yet I would like to add that Michaela Kušnieriková's emphasis on the need of our churches to open their windows to the fresh air of the world, and listen to and learn from it in the process of discernment reminds me of Dumitru Stăniloae's concept of 'open sobornicity', ${ }^{5}$ which claims that churches and theologies must always embrace humanity and the cosmos, and get enriched by what the 'other' has to offer to them. Unfortunately, in Orthodoxy, Stăniloae's concept of 'open sobornicity' remains a beautiful theoretical reflection on the need of the Orthodox Church to let itself be enriched by the world; in practice, however, the Orthodox Church tends to set itself up in opposition to the world rather than in dialogue and conversation with it.

Discernment is a journey and involves dialogue, conversation, and exchange of opinions; the praxis of discernment is, therefore, opposed to any form of parochialism, isolation, and self-sufficiencies. The praxis

5 Dumitru Stăniloae is widely considered to be one of the most important 20th-century Orthodox theologians and a towering figure of the Neo-patristic movement. He occupies a position in present-day Orthodoxy comparable to that of Karl Barth in Protestantism or Karl Rahner in Catholicism, as Kallistos Ware emphasised in his 'Foreword', to Dumitru Stăniloae, The Experience of God, Vol. I: Revelation and Knowledge of the Triune God, trans. Ioan Ionita and Robert Barringer (Brooklin: Holy Cross Orthodox Press, 1998), xxiv. For a comprehensive introduction into Stăniloae's concept of 'open sobornicity', see D. Stăniloae, 'Sobornicitatea deschisă,' Ortodoxia 23, no. 2 (1971): 165-180; Idem, 'Coordonatele ecumenismului din punct de vedere ortodox [The Coordinates of Ecumenism from the Orthodox Perspective],' Ortodoxia 19, no. 4 (1967): 494-540. For the secondary literature on the same topic, see Viorel Coman, "Open Sobornicity" and "Receptive Ecumenism": Fruitful Models of Ecumenical Interaction,' in Just Do It? Recognition and Reception in Ecumenical Relations: Proceedings of the 19th Academic Consultation of the Societas Oecumenica, Beihefte zur Ökumenischen Rundschau 117, ed. D. Heller and M. Hietamaki (Leipzig: Evangelische Verlagsanstalt), 241-251; Radu Bordeianu, '(In)Voluntary Ecumenism: Dumitru Staniloae's Interaction with the West as Open Sobornicity,' in Orthodox Constructions of the West, ed. G. Demacopoulos and A. Papanikolaou (New York: Fordham University Press, 2013), 240-253; Lucian Turcescu, 'Eucharistic Ecclesiology or Open Sobornicity?' in Dumitru Stăniloae: Tradition and Modernity in Theology, ed. L. Turcescu (Iași: The Center For Romanian Studies, 2002), 83-103. 
of discernment is ultimately rooted in a hermeneutic of receptivity, ${ }^{6}$ which presupposes attentiveness and openness to the insights of the other. As I have said, as an Orthodox, I have the impression that, very often, my own Church turns its dialogue with the world and the religious other into a monologue: the Orthodox Church's interaction with the world is very often limited to its mission to proclaim to the world the truth and revelation that the Church possesses. This is a unilateral approach as it is only the Church that helps the world discern what is good from what is wrong. There is not so much space for the opposite movement: the world can also help the Church throughout this process of discernment. As Metropolitan John Zizioulas stated at the International Congress of Orthodox Theological Schools (Sophia, Bulgaria, 2004), 'if the Church wants to speak to the world, it has to listen to it $[\ldots]$ we cannot self-define ourselves by opposing others, but can only do so through establishing a connection with them'. For the same theologian, the Orthodox Church's task of discerning what is good from what is wrong in our contemporary society needs a permanent conversation with the world and its modern achievements. To give just an example, many contemporary problems raised by biotechnology and the Orthodox Church's task to address these issues renders the dialogue between Eastern Christians and specialists in secular bioethics or ecological ethics of primary importance. As Zizioulas pointed out, the new realities, especially in the context of European Union, require active cooperation with the heterodox, including the secular world. ${ }^{7}$

6 Paul Murray's notion of 'receptive ecumenism' could equally be extended to the relationship between the Church and the world. The notion of 'receptive ecumenism' invites Christian traditions to place the self-critical question 'what, in any given situation, can one's own tradition appropriately learn with integrity from other traditions?' at the center of the ecumenical agenda. The basic principle of this ecumenical approach is that considerable further ecumenical progress is indeed possible but only if each tradition, both singly and jointly, makes a clear, programmatic shift from prioritizing the question 'what do our various others first need to learn from us?' to asking instead 'what do we need to learn and what can we learn - or receive - with integrity from our others?' See P. Murray (ed.), Receptive Ecumenism and the Call to Catholic Learning: Exploring a Way for Contemporary Ecumenism (Oxford: University Press, 2008); Idem, 'Receptive Ecumenism and Ecclesial Learning: Receiving Gifts for our Needs,' Louvain Studies 33, no. 1-2 (2008): 30-45; See also Antonia Pizzey, Receptive Ecumenism and the Renewal of the Ecumenical Movement: The Path of Ecclesial Conversion (Leiden: Brill, 2019). When applied to the relationship between the Church and the word, the same question takes the following form: 'What, in any given situation, can one's own tradition or Church appropriately learn with integrity from the world?'

7 Cf. Jason Byassee, 'Looking East: The Impact of Orthodox Theology,' Christian Century (28 December 2004). A couple of years ago, the same Orthodox Metropolitan 


\section{Discernment in Our Re-reading of the Past}

František Štěch's claim that discernment 'is also a practice of ongoing hermeneutical re-reading of experience and tradition' touches upon a very important function of diakrisis, especially when memory, tradition, and past experiences work as elements that build up ecclesial identities and strongly shape their future. Discernment in such situations is always a difficult task and practice, because, both individually and collectively, human persons tend to over-remember and over-emphasise some aspects of the past, while, at the same time, under-remembering or even intentionally forgetting other aspects that do not fit into their identity model or vision. That is why the practice of discernment in the act of remembering should seek to operate with a memory faithful to the truth of the past, making sure that no voices have been silenced, no events have been forgotten, and no central aspects have been neglected. I will offer two relevant examples in order to make my statement regarding remembering clear. All these examples that I use are taken from the Orthodox world; but the problem they reveal is of a universal type and concern.

The first example refers to the way in which some members of the Orthodox Churches in Eastern Europe tend to read the communist past of their countries. As the American theologian John Erickson pointed out in an article published in 2019, it is very common nowadays for the representatives of the Orthodox Church in Eastern countries such as Romania, Russia, Ukraine, to mention just a few of them, to remember - and even to over-remember - that a large number of Orthodox believers, clergy, and lay people alike, became victims of the communist régime in the past, being either unjustly incarcerated, tortured, persecuted, or killed. Without any doubt, it is our individual and collective moral duty to remember the victims of the communist régime; and not only the victims of the communism but all people who have suffered throughout history, in a way or another, injustices and atrocities, either in Europe or elsewhere in the world. It is not the act of remembering

acknowledge the need of the Orthodox Church to discern together with the modern world and not in opposition to it, when he said that the 'agenda of Theology is set by history'. To determine its agenda, Theology must discern the problems of the contemporary world first. And such a discernment is supposed to take place in dialogue and mutual conversation with the world. The Church discerns the problems of the world and can offer solutions to them if it cooperates with the world and listens to it. 
these victims that I call into question. The problem lies, as John Erickson emphasised, in the fact that, while Orthodox Churches are inclined to over-remember these victims of the communist régime, they incline to forget atrocities and injustices in which the members of the Orthodox Church have to a certain extent been complicit, such as the forced suppression of the Eastern Catholic Churches during the same communist regime for example. ${ }^{8}$ Unfortunately, these injustices, which were very often committed during that period with the silent consent of the members of the Orthodox Church, are either 'forgotten, relegated to a footnote, or simply deleted'. ${ }^{9}$

The second example refers to the way in which the very fundamentalist groups in the Orthodox Church read the agenda of the 20th-century Neo-Patristic movement to promote their current anti-ecumenical and anti-Western feelings. The Neo-Patristic movement ${ }^{10}$ was the most influential theological direction in 20th-century Orthodox Christianity. It consisted of a large group of 20th-century Orthodox thinkers (Georges Florovsky, Vladimir Lossky, and Dumitru Stăniloae) who advocated the need of Eastern theology to return to the patristic sources of Chris

8 John Erickson, 'The Temporal Dimension of Discernment: History and Memory,' St. Vladimir's Theological Quarterly 63, no. 1 (2019): 18. See also Robert Taft, 'Anamnesis, Not Amnesia: The "Healing Memories" and the Problem of "Uniatism",' 21st Kelly Lecture given at the University of St. Michael's College, Toronto, Canada, on the 1st of December 2000. The text of his lecture is available at https://www.royaldoors .net/wp-content/uploads/2015/03/Anamnesis-not-Amnesia.pdf [accessed on August 14, 2019]; Miroslav Volf, The End of Memory: Remembering Rightly in a Violent World (Grand Rapids and Cambridge: Eerdmans, 2016).

9 J. Erickson, 'The Temporal Dimension of Discernment,' 8. Related to what I have mentioned above about Eastern countries' reading of their communist past is also the fact that contemporary Romanian theologians and priests like to point out that since a lot of Christians of Romanian origin have been tortured during the communist persecution, the Romanian people and nation possesses naturally the vocation of sainthood and martyrdom. But those who make such claims forget that those who tortured and killed during the communist regime were also Romanians.

10 See Paul Ladouceur, Modern Orthodox Theology: 'Behold, I Make All Things New' (London: T\&T Clark, 2019), 95-122; Idem, 'Treasures New and Old: Landmarks of Orthodox Neopatristic Theology,' St. Vladimir's Theological Quarterly 56, no. 2 (2012): 191-228; Christos Filiotis-Vlachavas, 'La théologie orthodoxe, entre retour aux pères et appel de la modernité,' Revue des Sciences Religieuses 89, no. 4 (2015): 425-442; Ioan I. Ică jr., 'Modern and Contemporary Orthodox Theology: Key Moments, Key Figures, Developments, and Assessments,' in Orthodox Theology in the 20th Century and Early 21st Century: A Romanian Orthodox Perspective, ed. V. Ioniță (Bucharest: Basilica, 2013), 21-94; Andrew Louth, 'The Patristic Revival and its Protagonists,' in The Cambridge Companion to Orthodox Christian Theology, ed. M. B. Cunningham and E. Theokritoff (Cambridge: University Press, 2008), 188-203. 
tianity in order to renew itself and depart from the negative influences of Western scholasticism, which had permeated its ecclesiology, ethics, and spirituality for centuries. Even though the Neo-Patristic movement's attempt to liberate Eastern Christian theology from Western scholastic patterns of thought developed, to a certain extent, a politics of identity in which Orthodoxy defines itself in opposition to the West, ${ }^{11}$ the interaction of the movement with Roman Catholicism and Protestantism cannot be reduced to this hermeneutics of rejections; the agenda of the Neo-Patristic movement included an ecumenical component as well, ${ }^{12}$ which is completely ignored by the Orthodox fundamentalists groups because it does not fit their anti-Western and anti-ecumenical rhetoric. More can be said about the ecumenical interactions of the representatives of the Neo-Patristic movement and their approach to Western theology, but I stop here.

\section{False Forms of Discernment}

The article of Kateřina Bauer, František Štěch, and Michaela Kušnieriková has also engaged with the topic related to the complex relationship between discernment, on the one hand, and good and evil, on the other hand. For this reason, I would like to briefly refer to the phenomenon related to the embodiment of false forms of discernment, which is one of the many aspects of the mixture between good and evil, between what is true and what is false. The example coming from Eastern Orthodox tradition that I have in mind is linked to the so called self-proclaimed spiritual directors, mostly monks, who turn themselves into infallible organs of discernment and claim unshaken obedience to them. To quote Georgios Vlantis, the phenomenon of false spiritual directors in contemporary Orthodoxy - the phenomena

11 Pantelis Kalaitzidis, "From the "Return to the Fathers" to the Need for a Modern Orthodox Theology,' St. Vladimir's Theological Quarterly, 54, no. 1 (2010), 5-36.

12 The ecumenical component of the Neo-Patristic movement has been brought to light by Matthew Baker, 'Neopatristic Synthesis and Ecumenism: Toward the "Reintegration" of Christian Tradition,' in Eastern Orthodox Encounters of Identity and Otherness: Values, Self-Reflection, Dialogue, ed. A. Krawchuk and T. Bremer (New York: Palgrave Macmillan, 2014), 235-260; Brandon Gallaher, 'Ecumenism as Civilisational Dialogue: Eastern Orthodox Anti-Ecumenism and Eastern Orthodox Ecumenism. A Creative or Sterile Antinomy?' International Journal for the Study of the Christian Church (forthcoming 2019); and Viorel Coman, 'Revisiting the Agenda of the Neo-Patristic Movement,' The Downside Review 138, no. 2 (2018): 99-117. 
is usually called gherontism, elderism, or fatherism - is one of the many 'images of holiness that do harm'. ${ }^{13}$

The genuine practice of spiritual direction in Orthodoxy involves guiding a person to the process of theosis, that is, the process of growth in communion with God, human fellows, and the rest of creation. An authentic spiritual director is that person who can assist, by personal experience, the advancement of his/her disciple into spiritual maturity. ${ }^{14}$ Unfortunately, the charisma of genuine fatherhood/motherhood in Orthodox tradition can also be distorted, especially when the art of spiritual guidance succumbs to the thirst for power and dominance. I can use as an example the unfortunate events that took place after the Holy and Great Council of the Orthodox Church (Crete, 19-26 June 2016), when its decisions started to be contested by a group of fundamentalist people, who considered themselves bearers of the charisma of truth, entrusted by God with the task of discerning the correct path to be followed by contemporary Orthodoxy. ${ }^{15}$ The paper I respond to did not touch upon this issue when dealing with the question of discernment between good and evil - and probably because this is an issue confronting primarily the Orthodox world; but I think that this is a good example of moments when evil is clothed in good.

\section{Conclusions}

The article of Kateřina Bauer, František Štěch, and Michaela Kušnieriková on 'Helpful Models of Theological, Moral, and Spiritual

13 Georgios Vlantis, 'Images of Holiness That Do Harm,' Communio Viatorum 61, no. 1 (2019): 99-109. John A. Monaco, 'Contra Father-ism: On Spiritual and Theological Abuse,' Public Orthodoxy, https://publicorthodoxy.org/2019/08/16/contra-fatherism [accessed on August 19, 2019]; (See also Viorel Coman, 'Obnova pravoslavného hesychasmu dvacátého století a jeho obraz svatosti: Kritické zhodnocení, Teologické reflexe 24, no. 1 (2018): 46-56. The same issue has briefly been touched by Pantelis Kalaitzidis, 'Concluding Reflections to the Colloquium "The Forthcoming Council of the Orthodox Church: Understanding the Challenges", The Saint-Serge Institute, Paris, 18-20 October 2012,' St. Vladimir's Theological Quarterly 60, no. 1-2 (2016): 279-297.

14 See Irénée Hausher, Spiritual Direction in the Early Christian East Cistercian Studies Series, No. 116 (Kalamazoo: Cistercian Publications, 1990). The book was originally published in French in 1955.

15 The negative reactions of the fundamentalist groups have been criticised by several Orthodox theologians. See Paul Ladouceur, 'On Ecumenoclasm: Anti-Ecumenical Theology in Orthodoxy,' St. Vladimir's Theological Quarterly 61, no. 3 (2017): 323-355; Georgios Vlantis, 'Die Angst vor dem Geist: Das Heilige und Große Konzil und die orthodoxen Anti-Ökumeniker,' Ökumenische Rundschau 66, no. 1 (2017): 32-41. 
Discernment in Catholicism, Protestantism, and Orthodoxy' certainly offers excellent food for thought to anyone interested in the Christian practice of diakrisis and its theoretical and practical ramifications. Given the complexity of the topic explored in the article, it was not possible for me to comment upon all the issues that have been addressed by the authors. What my response intended to do was to offer a few general remarks related to the topic of discernment and to engage with those major aspects of the practice of discernment that in the article ask for an Eastern Orthodox reaction. Kateřina Bauer, František Štěch, and Michaela Kušnieriková do not claim to have exhausted the discussions on discernment. Undoubtedly, the practice of diakrisis is an ongoing journey and so is any serious theoretical reflection on discernment, which needs to continue and explore uncharted territories that will shed even more light on the topic at stake.

Research Foundation - Flanders (FWO) Faculty of Theology and Religious Studies, KU Leuven Sint-Michielsstraat 4 - box 3101 3000 Leuven Belgium E-mail: viorel.coman@kuleuven.be 